\title{
The Use of Tracker Application to Enchance Physics Teachers in Senior High School in Making Laboratory Video
}

\author{
Yulkifli $^{*}$, Ramli \\ ${ }^{1}$ Jurusan Fisika, Fakultas MIPA, Universitas Negeri Padang
}

*Correspondence: yulkifliamir@gmail.com; Tel.: +62-813-6341-3004

Diterima 26 Januari 2018, Disetujui 26 Januari Dipublikasikan Maret 2018

\begin{abstract}
During this time, practicum activities in the School have not gone well. In fact, practical activities can support the understanding of the theory or material Physics taught to students. In addition, the lab can also generate student motivation and passion, as well as develop the students' process skills by conducting experiments. Experimental activities are very useful for students if this activity has been planned and designed well by teachers. Currently, technological advances can help improve Physical practice in the School. One of them by using video based laboratory (VBL). VBL is a practical activity in the laboratory in the form of video-based educational software. Technical Guidance for Making Video-Based Laboratory Application Tracker for Physics Teacher in Teachers' Consultation in Subject (MGMP) of High School Physics (SMA) in Padang and Padang Panjang City ", This activity was held for 2 months with the activity stage is preparation, implementation and activity evaluation. Based on the planning, the activities have been successfully done well. Implementation of this activity by the way the teacher is guided using the application Tracker on Physics practicum activities. The output of this activity is the Digital Video Labaratory for teaching material with Tracker application for physics practicum activity, especially Regular Straight Motion (GLB), Straight Changed Motion (GLBB), Momentum and Impulse.
\end{abstract}

Key words: Laboratory Video, Learning physics, Physics experiment, Tracker, Video based laboratory

\section{Pendahuluan}

Salah satu faktor penunjang pembelajaran Ilmu Pengetahuan Alam (IPA) Fisika di SMA adalah pelaksanaan kegiatan praktikum. Fisika berkembang melalui metode ilmiah, dan kegiatan praktikum merupakan salah satu cara untuk memberikan pemahaman materi Fisika kepada siswa melalui metode ilmiah tersebut.

Implementasi kurikulum 2013 menghendaki pembelajaran fisika menerapkan kegiatan mengamati, menanya, mengumpulkan informasi, mengasosiasi dan mengomunikasikan sehingga siswa mengalami pembelajaran secara langsung dalam setiap kegiatan.

Kegiatan praktikum dapat mendukung pemahaman terhadap teori atau materi Fisika yang diajarkan pada siswa. Selain itu, praktikum juga dapat membangkitkan motivasi dan gairah belajar siswa, serta mengembangkan keterampilan proses siswa dengan melakukan eksperimen. Kegiatan praktikum akan sangat bermanfaat bagi siswa apabila kegiatan ini telah direncanakan dan dirancang dengan baik oleh guru.

Dalam buku Pedoman Pembuatan Alat Peraga Fisika Untuk SMA [1] dilaporkan bahwa berdasarkan hasil pengamatan dan penelitian di lapangan, kondisi sarana dan prasarana laboratorium khususnya untuk pembelajaran IPA di SMA/MA adalah:

1. Sangat minim fasilitas, alat dan bahan (zat kimia) yang ada jika dibandingkan dengan rasio jumlah pemakai laboratorium IPA.

2. Adanya kecenderungan biaya yang dialokasikan sekolah untuk penunjang kegiatan laboratorium tidak mencukupi.

3. Adanya kecenderungan pengguna laboratorium IPA tidak dapat menyelesaikan praktikumnya dengan baik karena waktu yang tersedia tidak mencukupi.

4. Praktikum yang telah direncanakan, sering tertunda pelaksanaannya karena beberapa bahan dan alat yang tersedia jumlahnya 
kurang sesuai dengan kebutuhan kegiatannya.

5. Belum dilakukan penataan terhadap fasilitas, alat dan bahan yang akan digunakan dalam kegiatan IPA.

6. Penggunaan fasilitas dan peralatan yang tersedia di laboratorium IPA belum secara optimal.

7. Laboratorium kurang difungsikan secara optimal sebagai tempat melaksanakan eksperimen.

Berdasarkan wawancara tim penulis dengan beberapa orang guru fisika yang tergabung dalam MGMP Fisika Kota Padang dan Kota Padang Panjang, ditemukan kondisi bahwa praktikum Fisika di Sekolah belum terlaksana dengan optimal. Kendala yang dikemukakan oleh guruguru tersebut adalah kurangnya peralatan dan bahkan tidak tersediannya peralatan praktikum Fisika di Sekolah. Oleh karena itu, jarang siswa diajak melakukan percobaan/praktikum dalam laboratorium. Hal ini tentunya, menjadi keprihatinan kita semua, karena praktikum dalam pembelajaran fisika di SMA sangat diperlukan untuk mendukung pembelajaran saintifik seperti yang diamanatkan dalam Kurikulum 2013. Permasalahan yang dihadapi dapat diidentifikasi sebagai berikut:

1. Beberapa guru belum punya kemampuan menggunakan aplikasi tracker sebagai media praktikum.

2. Perlunya ditumbuhkan keterampilan guru dalam penggunaan aplikasi tracker untuk membantu terlaksananya praktikum di sekolah.

Permasalahan ini juga senada dengan hasil penelitian yang dilakukan oleh Yulkifli dkk [2] melalui analisis pengunaan laboratorium IPA menghasilkan kesimpulan bahwa laboratorium IPA belum berfungsi secara optimal dikarenakan manajemen dan pengelolaan labor masih belum optimal. Tahun 2015-2017 Yulkifli dkk [3,4] kembali melakukan penelitian terkait kelengkapan set praktikum fisika, hasil penelitian menunjukkan bahwa peralatan praktikum Fisika masih minim dari segi kualitas dan kuantitas. Salah satu hasil penelitian terkait pengembangan alat pratikum adalah penggunaan video based laboratory (VBL).
Kemajuan teknologi pada zaman sekarang dapat membantu memperbaiki kegiatan praktikum Fisika di Sekolah yang menjadi perhatian saat ini. Salah satunya dengan menggunakan video based laboratory (VBL). VBL merupakan kegiatan praktikum dalam laboratorium berbentuk software edukasi berbasis analisis video.

Salah satu nama software berbasis VBL adalah Tracker. Tracker adalah software video analisis dan pemodelan yang dibangun dengan kerangka kerja menggunakan Java. Fitur yang disediakan termasuk pelacakan objek dengan posisi, kecepatan dan percepatan lapisan dan grafik, filter efek khusus, beberapa frame referensi, poin kalibrasi, profil garis untuk analisis spektrum dan pola gangguan, serta model dinamika partikel.

\section{Solusi/Teknologi}

Dengan alasan-alasan dan kenyataan di lapangan, kami dari tim Ipteks bagi Masyarakat (IbM) jurusan Fisika UNP mencarikan solusi terhadap permasalahan yang ditemui dilapangan. Solusi tersebut adalah kegiatan IbM dalam bentuk "Bimbingan Teknis Pembuatan Video Laboratory Berbasis Aplikasi Tracker", dengan mitra sebagai khalayak sasaran adalah pada MGMP Fisika SMA Kota Padang dan Kota Padang Panjang". Dalam bimteks ini guru akan diberikan pendalaman materi tentang Praktikum Fisika SMA, kemudian guru dibimbing menggunakan Aplikasi Tracker pada kegiatan praktikum Fisika SMA. Pelatihan ini dilaksanakan selama 2 bulan dan ditujukan kepada guru Fisika SMA yang tergabung dalam MGMP Fisika Kota Padang dan Kota Padang Panjang.

Target dan luaran yang diharapkan dari kegiatan bimteks ini adalah:

1. Terbantunya para guru Fisika SMA dalam mencari alternatif kegiatan praktikum

2. Meningkatnya kemampuan keterampilan Guru Fisika SMA dalam pembuatan video laboratory berbasis aplikasi tracker.

3. Diharapkan guru-guru berhasil membuat beberapa buah video laboratory berbasis aplikasi tracker dalam bentuk CD Pembelajaran untuk kegiatan praktikum dilaboratorium. 
4. Hasil-hasil kegiatan dipublikasikan dalam bentuk artikel ilmiah baik dalam seminar maupun dalam bentuk jurnal.

Untuk merealisasikan solusi yang telah ditawarkan dalam rangka menyelesaikan masalah kelompok MGMP Fisika SMA, maka metode pelaksanaan kegiatan penerapan ipteks ini dilakukan melalui lima tahapan. Tahapan yang dilaksanakan mulai dari penjajakan sampai dengan dihasilkannya produk berupa karya tulis dan publikasi ilmiah pada guru-guru yang tergabung dalam kelompok MGMP fasika SMA. Adapun tahap-tahap pelaksanaan kegiatan ini adalah

\section{1) Tahap survey atau penjajakan}

Dalam tahap ini dilakukan penjajakan dan penentuan lokasi kegiatan pengabdian dan pemilihan kelompok MGMP mitra yang membutuhkan bimbingan dalam menghasilkan karya tulis dan publikasi ilmiah.

2) Orientasi dan Diskusi

Orientasi dan diskusi dilakukan untuk mengidentifikasi permasalahan yang ada pada kelompok MGMP dan mendiskusikan solusi yang dapat dilakukan untuk mengatasi masalah tersebut. Disamping itu juga disusun rencana dan jadwal kegiatan bersama mitra.

3) Tahapan persiapan pelaksanaan

Dalam tahap persiapan pelaksanaan ini ada beberapa kegiatan yang akan dilakukan. Kegiatan-kegiatan tersebut antara lain, mengurus masalah perizinan pelaksanaan kegiatan.

4) Tahapan pelaksanaan

Pada tahap pelaksanaan ini, kelompok MGMP mitra akan diberikan pengetahuan tentang pendalaman materi tentang Praktikum Fisika SMA, kemudian guru dibimbing menggunakan Aplikasi Tracker pada kegiatan praktikum Fisika SMA.

5) Tahapan monitoring dan evaluasi

Tahapan ini berupa kegiatan pendampingan dalam bentuk monitoring dan evaluasiatas pelaksanaan kegiatan pengabdian yang telah dilakukan. Kegiatan ini dilakukan bersamasama oleh tim pengusul dan mitra dengan jadwal pelaksanaan sesuai dengan jadwal yang telah disepakati bersama. Secara rinci tahapan kegiatan, jenis kegiatan, alokasi waktu dan tempat pelaksanaan kegiatan dapat diperhatikan seperti dalam Tabel 1.

Tabel 1. Tahap-tahap kegiatan dan tempat pelaksanaan

\begin{tabular}{|c|c|c|c|}
\hline $\begin{array}{c}\text { Tahap } \\
\text { Kegiatan }\end{array}$ & Jenis Kegiatan & $\begin{array}{l}\text { Alokasi } \\
\text { Waktu }\end{array}$ & Tempat \\
\hline $\mathrm{I}$ & $\begin{array}{l}\text { Survey atau } \\
\text { penjajakan }\end{array}$ & $2 \mathrm{Jam}$ & $\begin{array}{l}\text { (Tempat } \\
\text { mitra) }\end{array}$ \\
\hline II & $\begin{array}{l}\text { Orientasi dan } \\
\text { diskusi }\end{array}$ & $3 \mathrm{Jam}$ & $\begin{array}{l}\text { Ruang sidang } \\
\text { jurusan } \\
\text { Fisika FMIPA } \\
\text { UNP }\end{array}$ \\
\hline III & $\begin{array}{l}\text { Tahapan } \\
\text { persiapan } \\
\text { pelaksanaan }\end{array}$ & $3 \mathrm{Jam}$ & $\begin{array}{l}\text { Pusat MGMP } \\
\text { Fisika SMA } \\
\text { dan Ruang } \\
\text { sidang jurusan } \\
\text { Fisika FMIPA } \\
\text { UNP }\end{array}$ \\
\hline IV & $\begin{array}{l}\text { Tahapan } \\
\text { pelaksanaan }\end{array}$ & $20 \mathrm{Jam}$ & $\begin{array}{l}\text { Pusat MGMP } \\
\text { Fisika SMA } \\
\text { Padang dan } \\
\text { Padang } \\
\text { Panjang }\end{array}$ \\
\hline \multirow[t]{2}{*}{ V } & $\begin{array}{l}\text { Monitoring dan } \\
\text { evaluasi }\end{array}$ & 2 Jam & $\begin{array}{l}\text { Pusat MGMP } \\
\text { Fisika SMA }\end{array}$ \\
\hline & Jumlah & 30 & $\begin{array}{l}\text { Jam }=3 \text { hari } \\
\text { kegiatan }\end{array}$ \\
\hline
\end{tabular}

\section{Hasil dan Diskusi}

Pelaksanaan kegiatan pengabdian kepada masyarakat dilakukan secara bertahap. Keseluruhan ada 5 tahap yaitu: Tahap Survey, Tahap Orientasi dan diskusi, Tahap Persiapan, Tahap Pelaksanaan dan Tahap Monitaoring dan Evaluasi kegiatan.

\section{Tahap Survey}

Tahap survey atau penjajakan dilakukan ketika proses penentuan khalayak sasaran, yaitu Guruguru fisika yang tergabung dalam MGMP Fisika SMA Kota Padang dan Kota Padang Panjang. Pemilihan Khalayak sasaran ini berdasarkan permintaan dari kedua MGMP tersebut. Tempat pelaksanaan kegiatan disepakati di sekretariat MGMP Fisika Kota Padang, namun karena alasan kendala repotnya membawa alat percobaan untuk bahan analisis vidoe dengan tracker ke lapangan maka ditetapkan tempat pelaksanaan di FMIPA UNP.

\section{Tahap Orientasi dan Diskusi}


Tahap orientasi dan diskusi dilakukan untuk mengindentifikasi permasalahan yang akan di jadikan topik kegiatan pengabdian, Diskusi dilakukan dengan Ketua MGMP kedua khalayak sasaran. Disepakati permasalahan yang akan di selesaikan adalah bagaimana mencari alternatif lain dalam menggunakan dan melakukan kegiatan praktikum dilaboratorium dan menganalisnya menggunakan grafik, maka disepakati adalah penggunaan analisis video dengan tracker. Selain dengan ketua MGMP juga dilakukan wawancara dengan beberapa guru fisika pada kedua khalayak sasaran tersebut, ditemukan kondisi bahwa praktikum Fisika di Sekolah belum terlaksana dengan optimal. Kendala yang dikemukakan oleh guru-guru tersebut adalah kurangnya peralatan dan bahkan tidak tersediannya peralatan praktikum Fisika di Sekolah. Oleh karena itu, jarang siswa diajak melakukan percobaan/praktikum dalam laboratorium.

\section{Tahap Persiapan Pelaksanaan}

Tahap persiapan adalah tahap untuk menyiapkan kegiatan sesaui dengan perencaaan yang sudah disepakti dengan kedua khalayak sasaran. Kegiatan akan berlangsung dengan baik jika dilakukan persiapan dengan baik. Secara umum persiapan kegiatan pegabdian dimulai dari diskusi dengan ketua MGMP. Tahap ini adalah memastikan kembali lokasi kegiatan pengabdian, surat undangan, bahan bahan yang akan dijadikan sumber belajar/bimtek. Berdasarkan kesepakatan dengan kedua belah pihak disepakati kegiatan dilakukan sebanyak 2 kali pertemuan dengan $2 \mathrm{x}$ $8 \mathrm{JP}$ atau 2 hari. Yaitu pada tanggal 30 september dan 01 oktober 2017. Untuk memudahkan koordinasi kegiatan maka Tim pengabdi bekerjasama dengan pengurus MGMP Fisika SMA Kota Padang dan Kota Padang Panjang. Tim pengabdi berbagi peran dengan Pengurus MGMP, tim pengabdi bertanggung jawab dalam mempersipakan materi workshop, narasumber dan tempat kegiatan, sedangkan pengurus MGMP bertangung jawab menghadirkan anggotanya pada saat kegiatan.

\section{Tahapan Pelaksanaan}

Tahap pelaksanaan dilakukan dalam bentuk kegiatan tatap muka sebanyak 2 kali, yaitu tanggal 30 September 2017 dan 01 Oktober 2017. Pembukaan kegiatan dilakukan di Gedung Pertemuan IPA Terpadu UNP Padang. Pembukaan dihadiri oleh Pengurus berserta anggota MGMP Fisika Propinsi, Tim Pengabdian dan Wakil Dekan I FMIPA UNP Dr. Yulkifli, S.Pd., M.Si, sekaligus memberikan sambutan dan membuka acara kegiatan pengabdian. Kegiatan pembukaan dihadiri oleh 45 orang peserta yang berasal dari anggota MGMP Fisika Sumatera Barat.

Pertemuan kedua dilakukan tanggal 01 Oktober 2017. Kegiatan pada pertemuan kedua dikembangkan dengan pemaparan materi membuat laboratory video berbasis tracker untuk meningkatkan kemampuan guru fisika dalam kegiatan praktikum. Pada kegiatan kedua ini dihadiri oleh 16 peserta. Foto-foto kegiatan diperlihatkan dalam Gambar 1 dan Gambar 2.

Pada kegiatan kedua ini diikuti oleh 19 peserta dengan dan para peserta dibimbing membuat laboratory video berbasis aplikasi tracker dan hasil bimbingan akan dikumpulkan dan dievaluasi oleh narasumber, pada akhir kegiatan peserta diberikan angket untuk menilai keterlaksanaan kegiatan yang sudah dilakukan. Hasil dari angket yang telah dibagikan kepada peserta berguna untuk perbaikan kegiatan pengabdian berikutnya.

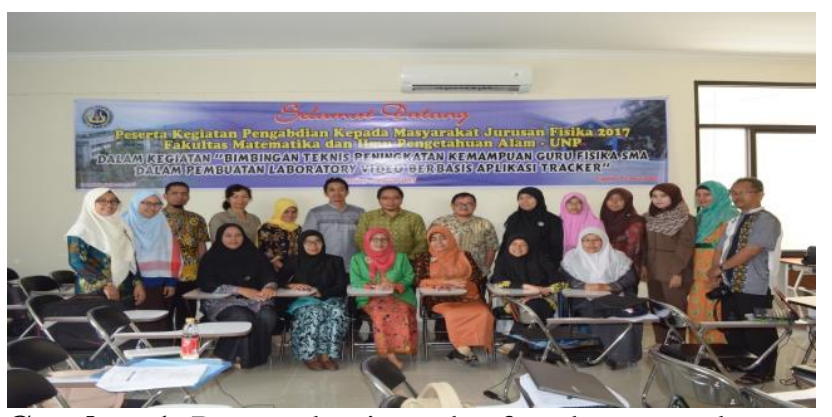

Gambar 1. Peserta kegiatan berfoto bersama dengan narasumber

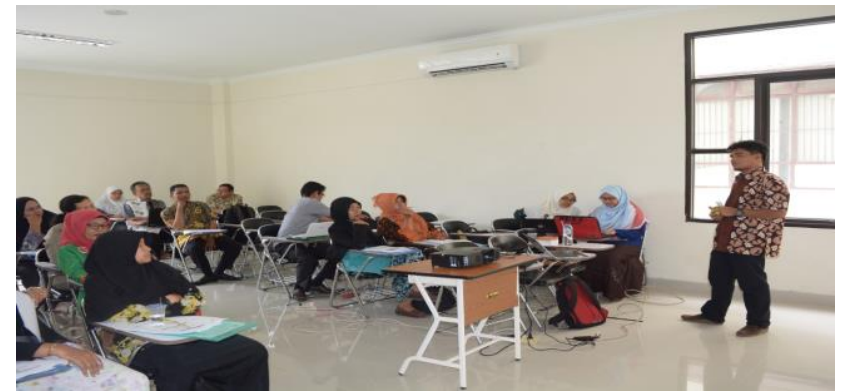

Gambar 2. Narasumber memberikan materi pelatihan 


\section{Tahap Monitoring dan Evaluasi Kegiatan}

Kegiatan monitoring dilakukan selama proses kegiatan berlangsung, semua peserta antusian mengikuti kegiatan hal ini ditandai dengan aktifnya seluruh peserta mengikuti dan mencoba membuat vidoe untuk percobaan impuls dan momentum. Untuk mengevaluasi keterlaksanaan kegiatan Bimbingan Teknis pembuatan laboratory video berbasis tracker dilakukan, maka di sebarkan angket evaluasi. Angket terdiri dari dua buah, yaitu angket yang berhubungan dengan Penyelenggaraan Kegiatan dan Angket yang berhubungan dengan Penyajian Instruktur. Hasilnya diuraikan di bawah ini.

\section{Hasil Analisis Angket Penyelenggaraan Kegiatan}

Angket penyelenggaraan Kegiatan ini disebarkan bertujuan untuk mengevaluasi selama kegiatan dilaksanakan. Jumlah angket yang dibagikan adalah 16 buah. Jumlah angket yang dikumpulkan 16 buah. Berdasarkan analisis persentase terhadap angket diperoleh informasi sebagai berikut yang ditunjukkan pada Gambar 3 .

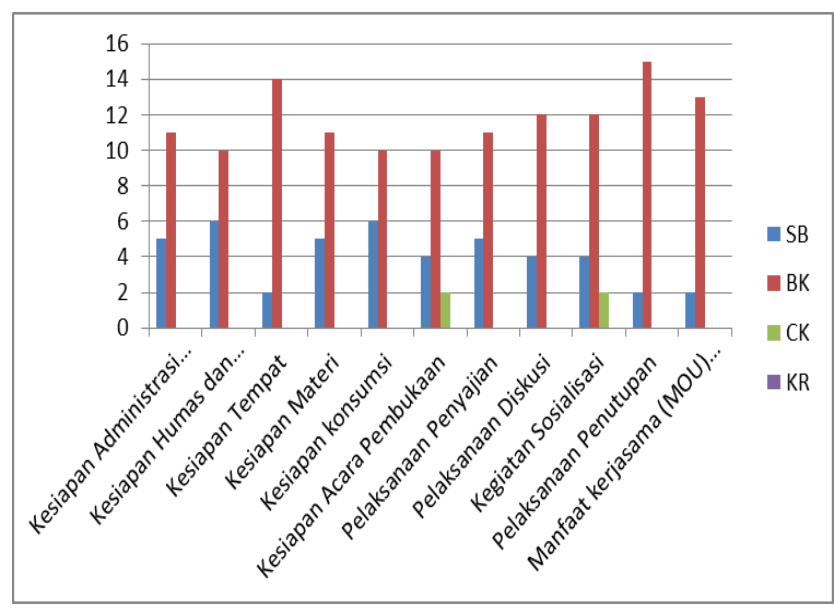

Gambar 3. Grafik Analisis Angket Penyelenggaraan Kegiatan

Secara umum segala aspek dalam penyelenggaraan kegiatan dinilai baik oleh peserta karena pada setiap aspek pada umumnya dikategorikan baik oleh lebih dari 10 dari 16 peserta. Nilai tertinggi baik berada pada indikator pelaksanaan penutupan, indikator ini dijawab oleh 15 pesertta dari 16 peserta. Nilai indikator terendah (Kurang) berada pada indikator kesiapan acara pembukaan dimana hal ini dinilai baik oleh. Pembukaan kurang berjalan sesaui rencana dikarenakan banyaknya peserta yang terlambat datang sehingga waktu yang dialokasikan. Hal ini menunjukkan bahwa kegiatan terlaksana dengan baik.

\section{Hasil Analisis Angket Penyajian Instruktur}

Angket Penyajian Instruktur ini disebarkan bertujuan untuk mengevaluasi penyajian instruktur selam kegiatan dilaksanakan. Jumlah angket yang di edarkan adalah 16 buah, jumlah angket yang dikemblikan 16 buah.Berdasarkan analisis persentase terhadap angket diperoleh informasi sebagai berikut yang ditunjukkan pada Gambar 4.

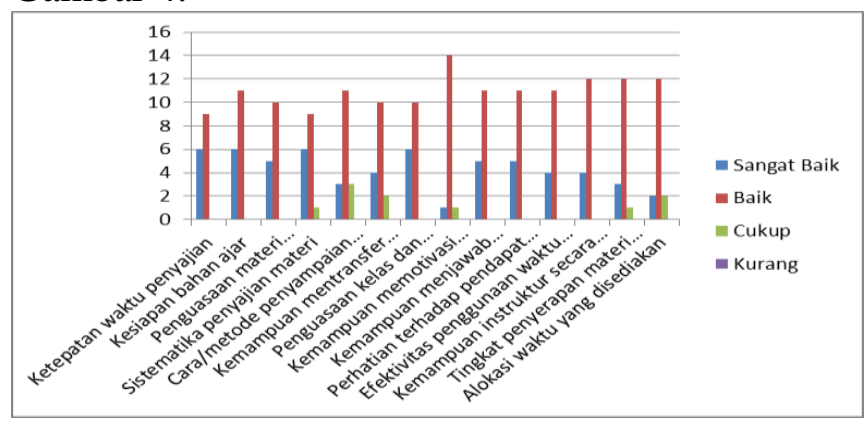

Gambar 4. Grafik Analisis Angket Penyajian Instruktur

Terlihat pada Gambar 4 bahwa secara umum peserta pengabdian mamberikan respon yang baik terhadap semua indikator pada angket yang telah diisi oleh peserta yang mengikuti pengabdian masyarakat yang telah dilakukan. Ada 16 orang peserta bimtek yang mengisi angket evaluasi, terdapat persentase tertinggi untuk hasil evaluasi penyajian instruktur ada pada kategori baik terlihat pada kemampuan memotivasi pesera bimbingan teknis yang dinilai baik oleh 14 orang peserta, diikuti dengan kemampuan instruktur secara keseluruhan, tingkat penyerapan materi serta alokasi waktu dan efektivitas penggunaan waktu. Respon paling rendah pada indikator metoda penyampaian materi oleh narasumber yang dinilai cukup oleh 3 orang peserta.

\section{Kesimpulan}

Kegiatan yang telah dilakukan sangat memberi arti terhadap MGMP Fisika Sumatera Barat sehingga kegiatan ini perlu dilanjutkan secara 
kontinu untuk menyelesaikan masalah-masalah yang ditemui guru-guru dilapangan. Berdasarkan target dan luaran yang diharapkan dari kegiatan maka dapat disimpulkan beberapa hasil yang telah dicapai:

1. Telah tersosialisasinya program PKM pada guru guru-guru Fisika yang tergabung dalam MGMP Guru Fisika Sumatera Barat, Hal ini dapat dibuktikan dengan mampunya guru merencanakan pengembangan karirnya dan meningkatnya kompetensi guru-guru fisika SMA Sumatera Barat dalam kegiatan praktikum.

2. Telah terciptanya suatu kelompok kerja guru yang mempunyai visi dan misi yang sama dalam mengembangkan karirnya. Sehingga dapat meningkatnya kesadaran guru-guru mata pelajaran fisika SMA akan pentingnya membuat karya tulis dan publikasi ilmiah untuk pengembangan karir berkelanjutan

\section{Ucapan Terima Kasih}

Penulis mengucapkan terimakasih kepada Universitas Negeri Padang yang telah mendanai kegiatan ini melalui skim Ipteks bagi Masyarakat (IbM) dana PNBP tahun 2017. Ucapan terima kasih juga disampaikan kepada seluruh peserta yang mengikuti kegiatan ini khususnya guru-guru Fisika yang tergabung dalam MGMP Fisika kota Padang dan kota Padang Panjang.

\section{Pustaka}

[1] Dirjendikmen, 2011, Pedoman Pembuatan Alat Peraga Fisika Untuk SMA, Jakarta, Kementrian Pendidikan dan Kebudayaan.

[2] Yulkifli, (2014), Pengembangan Perangkat Perkuliahan Pengelolaan Laboratorium Berbasis KKNI Untuk Mahasiswa Pendidikan Fisika PPS $U N P$. Laporan Hibah Pascasarjana UNP. Laporan Penelitian dana PNBP.

[3] Yulkifli, 2015. Analisis Materi Perangkat Perkuliahan Pengelolaan Laboratorium Berbasis KKNI. Jurnal Esakta Vol. 1. Tahun XVI Februari 2015, ISSN 1411-3724

[4] Yulkifli. 2016. Desain Pembuatan Alat-Alat Praktikum Berbasis Teknologi Digital sebagai Pendukung Perangkat Mata Kuliah Pengembangan Alat Laboratorium Fisika Berbasis KKNI untuk Mahasiswa Pendidikan Fisika PPS UNP. Laporan Penelitian Hibah Dosen Pascasarajana 2016. 